\title{
Health of Herring Gulls (Larus argentatus) in Relation to Breeding Location in the Early 1990s. III. Effects on the Bone Tissue
}

\author{
Glen A. Fox ${ }^{1}$, Rebecca Lundberg' ${ }^{2}$ Carolina Wejheden ${ }^{2}$, Lars Lind ${ }^{3}$, \\ Sune Larsson ${ }^{4}$, Jan Örberg ${ }^{5}$, and P. Monica Lind ${ }^{2}$ \\ ${ }^{1}$ Canadian Wildlife Service, National Wildlife Research Centre, Carleton University, Ottawa, Ontario, \\ Canada, ${ }^{2}$ Institute of Environmental Medicine, Karolinska Institutet, Stockholm, Sweden, ${ }^{3}$ Department \\ of Medical Sciences, ${ }^{4}$ Department of Orthopedics, Uppsala University Hospital, and ${ }^{5}$ Department \\ of Environmental Toxicology, Uppsala University, Uppsala, Sweden
}

\begin{abstract}
Health effects associated with the Great Lakes environment were assessed in adult herring gulls (Larus argentatus) in the early 1990s, including the size and quality of their bones. Femurs were excised from 140 individuals from 10 colonies distributed throughout the Great Lakes and 2 reference colonies in Lake Winnipeg (freshwater) and the Bay of Fundy (marine). Femurs of gulls from the Great Lakes differed from the freshwater or marine reference for 9 of 12 variables of size, composition, and strength assessed using peripheral quantitative computed tomography (pQCT) and biomechanical testing. Femurs of Great Lakes gulls were significantly smaller in length $(-2.9 \%)$, periosteal circumference $(-2.4 \%)$, and crosssectional area $(-5.4 \%)$ than freshwater reference birds. Femurs of the Great Lakes gulls had a lower significant cortical bone mineral content $(-8.1 \%)$ and density $(-2 \%)$ than the marine reference. A significant increase in the amount the bone could bend before it broke $(+34 \%)$ and the energy required to break it $(+44 \%)$ and a significant decrease $(-16.3 \%)$ in stiffness during three-point biomechanical bending test were also detected in Great Lakes versus the freshwater gulls. These differences are indicative of impaired mineralization. When divided into high and low 2,3,7,8-tetrachlorodibenzo-p-dioxin toxicity equivalent (TCDD-TEQ) colonies, the amount the bone could bend before it broke and the energy required to break it were significantly higher in the high TEQ colonies, but not high polychlorinated biphenyl (PCB) colonies. Breeding location and dietary choices of Great Lakes herring gulls in the early 1990s resulted in modulations of physiological processes
\end{abstract}

Received 31 January 2008; accepted 16 May 2008.

We thank K. Grasman, D. Jeffrey, and B. Hanbidge for assistance with the collection of gulls and tissues. We thank N. Wheelwright for hospitality and access to Kent Island. This project was supported by the Great Lakes Action Plan and FORMAS (The Swedish Research Council for Environment, Agricultural Sciences and Spatial Planning), grant 216/2006-1306, and Karolinska Institutet Foundation.

Address correspondence to Glen A. Fox, 877 Ridley Blvd., Ottawa, ON, K2A3P4, Canada. E-mail: glen.Afox@gmail.com that affected the size, mineralization, and biomechanical properties of bone.

Bone tissue provides the body with a rigid, hard framework that protects internal organs, maintains body posture, and provides leverage for muscles, thus enabling locomotion and specific motor functions. All bones consist of living cells embedded in a mineralized collagenous matrix. The mineralized component is composed of hydroxyapatite $\left[\mathrm{Ca}_{5}\left(\mathrm{PO}_{4}\right)_{3}(\mathrm{OH})\right]$, creating a metabolic reservoir of calcium and phosphate salts whose homeostasis is regulated by mechanisms coordinated by bone together with the kidneys and the parathyroid glands. Bone is formed and destroyed (remodeled) continuously in response to physical stresses, estrogens, and other hormones (Seibel et al., 1999). Bone tissue homeostasis is also influenced by a variety of dietary factors including calcium, magnesium, potassium, copper, zinc, silicon, and sodium; vitamins $\mathrm{D}_{3}, \mathrm{C}, \mathrm{A}, \mathrm{K}$, and $\mathrm{B}_{12}$; and macronutrients such as protein and fatty acids (Lanham-New \& Bonjour, 2003).

Bone tissue homeostasis is also influenced by environmental pollutants. The metals cadmium (Bhattacharyya et al., 1988), aluminum (Hahn, 1989; Firling et al., 1999), and lead (Potula et al., 2006) are known to induce harmful effects on bone tissue. Experimental studies suggest that bone tissue could be an important target for a number of endocrine-disrupting persistent organohalogen pollutants, including hexachlorobenzene (Andrews et al., 1988), polychlorinated biphenyls (PCBs) (Andrews, 1989; Hoffman et al., 1996; Lind et al., 1999, 2000; Lundberg et al., 2006), and polychlorinated dibenzo- $p$-dioxins (PCDD) (Jämsä et al., 2001; Miettinen et al., 2005).

Alterations in the composition and amount of bone and its geometry affect different aspects of its mechanical properties, including the amount of energy it can absorb before breaking 
and its stiffness. The stiffness of bones is largely dependent on the degree of mineralization. Unlike the widely used dualenergy x-ray absorptionmetry (DEXA) technique, bone mineral density (BMD) measurements by peripheral quantitative computed tomography (pQCT) imaging are not confounded by bone size. The pQCT technique allows selective measurement of cortical density, bone area, cortical area, cortical thickness, and periosteal and endosteal circumference. The biomechanical determinants of bone strength can be quantified by measuring the load necessary to break the bone and the amount of bending at the time of failure using the three-point bending method. This information is used to calculate the energy required and the bone's stiffness. These are the four most important basic variables when describing the mechanical properties of a structure such a long bone.

Studies of free-ranging wildlife including East Greenland polar bears (Ursus maritimus) (Sonne et al., 2004), Baltic gray seals (Halichoerus grypus) (Lind et al., 2003), mink (Mustela vison) (Beckett et al., 2005), American alligators (Alligator mississippiensis) (Lind et al., 2004), clapper rails (Rallus longirostris) (Rodriguez-Navarro et al., 2006), and great blue (Ardea herodius) (Hart et al., 1991) and gray heron (A. cinerea) (Thompson et al., 2006) chicks exposed to ambient mixtures of pollutants have revealed negative effects on bone tissue.

Herring gulls are long-lived and breed in both the freshwater and marine environments. As adults, herring gulls in the Great Lakes basin form what is essentially an isolated, closed population (Weseloh, 1984; Yauk \& Quinn, 1999) of year-round residents (Gilman et al., 1977; Weseloh, 1984). The choice of breeding location constrains the variety, quantity, and quality of food available, and individual preferences/specializations (i.e., lifestyle) greatly influence what is consumed by this opportunistic species (Fox et al., 1990; Ewins et al., 1994; Hebert et al., 1999b). Because much of the chemical pollution of the Great Lakes results from point sources, it differs in quantity and nature among lakes, and between sites within lakes (Hebert et al., 1999a). Gulls that breed in colonies north of $44^{\circ} 30^{\prime}$, where the lakes ice over for extended periods in winter, must migrate to more southern lakes where their diet differs and pollutant exposure is greater (Hebert, 1998). Diet quality varies among lakes and is correlated with female body condition, egg size, and productivity (Hebert et al., 2002).

The health of adult herring gulls resident within the five Great Lakes was assessed relative to individuals breeding in colonies located on freshwater and marine habitats outside the Great Lakes basin, using an intensive cross-sectional survey, sampling colonies during incubation in the early 1990s (Fox et al., 2002). By sampling adults at the same point in the breeding cycle using a single method of capture, the influence of season, reproductive condition, method of capture, and to a lesser extent age was effectively controlled, thereby allowing us to detect the influences of sex, local environment (including the bioavailability of pollutants), and availability and nutritional quality of food.
Tissue pollutant concentrations (Fox et al., 2002), hematological effects (Grasman et al., 2000), decreased DNA strand length (Fox et al., 2005), and biochemical, cellular, and histopathological variables of health (Fox et al., 2007a, 2007b) have been reported previously for these individuals. Gulls from one or more Great Lakes differed from one or both reference colonies for 17 of 19 biochemical variables, whereas the freshwater and marine reference sites differed for only 3 (Fox et al., 2007b). Herring gulls from some of the Great Lakes had lower plasma calcium, inorganic phosphorus, and magnesium concentrations than those from the reference colonies. Since bone represents the major reservoir of the minerals in the body, their circulating concentrations are indicators of bone and mineral dynamics. These minerals are leaked from the body by damaged kidneys. Fox et al. (2007a) found that chronic granulomatous interstitial nephritis was more severe in gulls from Great Lakes colonies and associated with pollutants. These findings prompted our investigation of bone composition, size, and strength in these gulls using pQCT and three-point bending which is reported here. Our aim was to determine whether properties of bones of these adult gulls differ spatially in a manner consistent with pollutant exposure.

\section{MATERIALS AND METHODS}

\section{Study Sites}

Collections were made from 10 colonies, representing all 5 Great Lakes and the Detroit River, and included colonies for which there was or was not historical evidence of point source pollution or adverse reproductive effects. For comparison, a colony from Lake Winnipeg was chosen as a reference freshwater lake with comparable surface area, but without obvious point source pollution. Kent Island, in the Bay of Fundy, was chosen as a marine, and therefore iodine-sufficient, reference colony with low levels of pollution (Table 1).

\section{Sampling}

Adult herring gulls were collected under federal permit using protocols and procedures approved by the National Wildlife Research Centre Animal Care Committee for the Canadian Council on Animal Care as described previously (Fox et al., 2002, 2007b). Briefly, collections were timed to coincide with mid-incubation (d 7 to 21 of the 28-d incubation period. The incubating gulls were trapped on their nests using self-triggered drop traps. Gulls were weighed to the nearest $10 \mathrm{mg}$; blood was collected and various organs and tissues were collected and preserved appropriately for biochemical assays, histology, or contaminant analysis (Fox et al., 2002, 2007a, 2007b). Sex was determined by gonadal inspection. The left femur was excised, partially defleshed, and placed in an airtight polyethylene "Whirl-Pac" bag, placed on ice, and frozen at $-40^{\circ} \mathrm{C}$ upon return to the National Wildlife Research Centre. In May 2005, the bags containing femurs were shipped on dry 
TABLE 1

Details of Locations of Collection Sites of Adult Herring Gulls, Year, and Geographic and Exposure Codes

\begin{tabular}{llccc}
\hline Region/lake & \multicolumn{1}{c}{ Location } & Latitude, longitude & Year & Group $^{a}$ \\
\hline L. Ontario & Scotch Bonnet Island, eastern basin & $43^{\circ} 50^{\prime} \mathrm{N}, 77^{\circ} 30^{\prime} \mathrm{W}$ & 1991 & GLs, HTEQ, HPCB \\
L. Ontario & Hamilton Harbour, western shore & $43^{\circ} 17^{\prime} \mathrm{N}, 79^{\circ} 50^{\prime} \mathrm{W}$ & 1991 & GLs, LTEQ, HPCB \\
L. Erie & Middle Sister Island, central western basin & $41^{\circ} 51^{\prime} \mathrm{N}, 83^{\circ} \mathrm{0} 0^{\prime} \mathrm{W}$ & 1993 & GLs, LTEQ, HPCB \\
L. Erie & Middle Island, off Pelee Island, western basin & $41^{\circ} 41^{\prime} \mathrm{N}, 82^{\circ} 41^{\prime} \mathrm{W}$ & 1991 & GLs, HTEQ, HPCB \\
Detroit River & Fighting Island & $42^{\circ} 12^{\prime} \mathrm{N}, 83^{\circ} 07^{\prime} \mathrm{W}$ & 1991 & GLs, LTEQ, HPCB \\
L. Huron & Chantry Island near Southhampton, ON & $44^{\circ} 30^{\prime} \mathrm{N}, 81^{\circ} 27^{\prime} \mathrm{W}$ & 1991 & GLs, LTEQ, LPCB \\
L. Michigan & Big Gull Island, west of Beaver Island, & $45^{\circ} 31^{\prime} \mathrm{N}, 86^{\circ} 43^{\prime} \mathrm{W}$ & 1991 & GLs, HTEQ, HPCB \\
& $\quad$ northeast end & & & \\
L. Michigan & Kidney Island, mouth of Fox River, in lower & $44^{\circ} 34^{\prime} \mathrm{n}, 88^{\circ} 00^{\prime} \mathrm{W}$ & 1991 & GLs, HTEQ, LPCB \\
& $\quad$ Green Bay & & & \\
L. Superior & Island east of mouth of Aquasabon River, & $48^{\circ} 46^{\prime} \mathrm{N}, 87^{\circ} 05^{\prime} \mathrm{W}$ & 1991 & GLs, HTEQ, LPCB \\
& $\quad$ near Terrace Bay, ON & & & \\
L. Superior & Granite Island in Black Bay, north shore & $48^{\circ} 43^{\prime} \mathrm{N}, 88^{\circ} 28^{\prime} \mathrm{W}$ & 1991 & GLs, LTEQ, LPCB \\
L. Winnipeg & Unnamed island in north basin, near Grand & $53^{\circ} 17^{\prime} \mathrm{N}, 99^{\circ} 05^{\prime} \mathrm{W}$ & 1991 & Freshwater, LTEQ, LPCB \\
Bay of Fundy & $\quad$ Rapids, MB & & & \\
& Kent Island, off Grand Manan, NB & $44^{\circ} 43^{\prime} \mathrm{N}, 66^{\circ} 46^{\prime} \mathrm{W}$ & 1991 & Marine, L TEQ, LPCB \\
\hline
\end{tabular}

${ }^{a}$ Grouping: GLs $=$ Great Lakes colony, LTEQ = low TCDD-TEQs $(<500$ pg/g), HTEQ = high TCDD-TEQs $(>500$ pg/g), LPCB $=$ low $\Sigma$ PCBs $(<9500 \mathrm{ng} / \mathrm{g})$, and HPCB $=$ high $\Sigma$ PCBs $(>9500 \mathrm{ng} / \mathrm{g})$.

ice to Karolinska Institute, Stockholm, Sweden. They were stored at $-20^{\circ} \mathrm{C}$ until August 2005, and thereafter completely defleshed and their size, composition, and biomechanical properties were determined.

\section{Peripheral Quantitative Computed Tomography (pQCT)}

The bone composition and dimensions were evaluated by peripheral quantitative computed tomography (pQCT; Stratec XCT Research SA+ with software version 5.50R; Norland Stratec Medizintechnik GmbH, Birkenfeld, Germany). The pQCT method has been used, with modifications, in previous studies (Lind et al., 2000, 2004; Lundberg et al., 2006). Before analysis, the bones were placed in plastic test tubes filled with Ringer solution (1 L contains $0.3 \mathrm{~g}$ Tris; $0.24 \mathrm{~g} \mathrm{CaCl}_{2}\left(\mathrm{H}_{2} \mathrm{O}\right) ; 0.4 \mathrm{~g}$ $\mathrm{KCl}$; and $2.05 \mathrm{ml} 1 \mathrm{M} \mathrm{HCl} ; \mathrm{pH}$ 7.4). The bones were scanned, in the test tubes with the Ringer solution, at $40 \%$ of the total bone length from the distal tip. The bones were scanned only at the diaphysis because in birds the medullary (trabecular) bone formation alternates with periods of bone depletion due to the ovulation-oviposition cycle. A voxel size of $0.07 \mathrm{~mm}$ was used and the scan line was adjusted using the scout view of the pQCT system. A threshold of $710 \mathrm{mg} / \mathrm{cm}^{3}$ was used to define cortical bone. For the analyses, measurements of total cross-sectional area $\left(\mathrm{CSA}\right.$ in $\mathrm{mm}^{2}$ ), cortical bone mineral content (BMC in $\mathrm{mg} / \mathrm{mm}$ ), cortical bone mineral density (BMD in $\mathrm{mg} / \mathrm{cm}^{3}$ ), cortical area $\left(\mathrm{mm}^{2}\right)$, cortical thickness $(\mathrm{mm})$, periosteal circumference $(\mathrm{mm})$, and endosteal circumference $(\mathrm{mm})$ were used.

To evaluate the reproducibility of the pQCT measurements, the coefficients of variation $(\mathrm{CVs})$ for the different variables were calculated from 10 repeated measurements with a single sample being repositioned before each measurement. The coefficients of variation for the 10 different pQCT-measurements were as follows: $0.35 \%$ (cortical area), $0.41 \%$ (BMD), $0.60 \%$ (BMC), $1.12 \%$ (periosteal circumference), $1.56 \%$ (cortical thickness), $1.88 \%$ (endosteal circumference) and $2.26 \%$ (CSA).

\section{Biomechanical Testing}

Three-point bending was used to measure bone strength (electromechanical material testing machine, Avalon Technologies, Rochester, MN) using a span length of $15 \mathrm{~mm}$ between the support bars and a loading speed of $1 \mathrm{~mm} / \mathrm{sec}$. The load was applied to the mid-diaphyseal area of the femur using a wedge-shaped metal bar that was directly connected to the load cell. The load and displacement were sampled with a frequency of $50 \mathrm{~Hz}$ and stored digitally. Displacement at failure (the total amount of movement of the load in $\mathrm{mm}$ from the moment of contact with the bone surface until the bone fractured) and the load applied at the moment when the bone fractured were recorded in newtons $(\mathrm{N})$. The data accumulated during each test were used to construct a load-displacement curve (Figure 1). The area under the curve defines the amount of energy absorbed until failure (breakage) measured in joules (J). The maximum slope of the load-displacement curve is defined as the bone's stiffness to failure $(\mathrm{N} / \mathrm{mm})$. The same equipment and methodology was used in several studies (Lind et al., 2000; Lundberg et al., 2006, 2007) with slight adjustments to accommodate the specific bones being tested. 


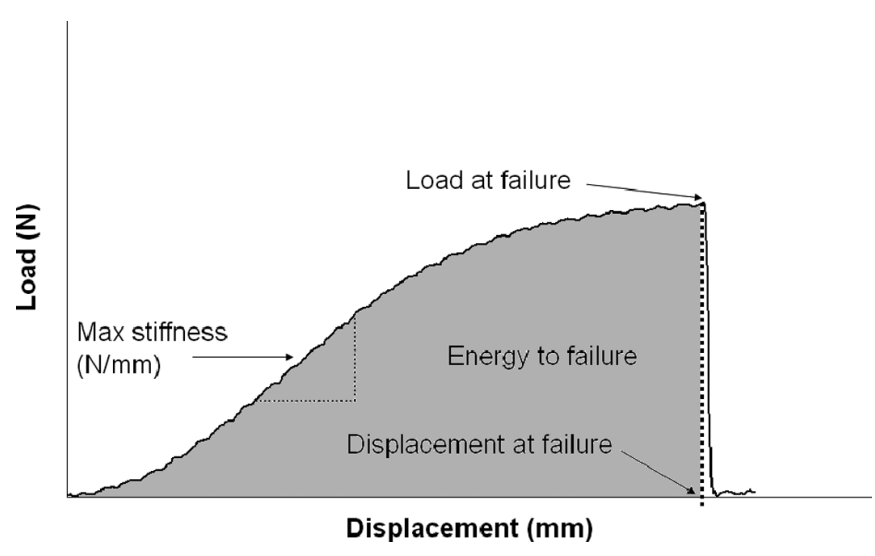

FIG. 1. Load-displacement curve achieved when subjecting the bone specimen to three-point bending. The four variables used to describe the mechanical properties of the bone were load at failure $(\mathrm{N})$, displacement at failure $(\mathrm{mm})$, energy to failure $(\mathrm{J})$, and stiffness $(\mathrm{N} / \mathrm{mm})$.

\section{Statistics}

Colonies were combined by lake, and grouped as Great Lakes (GLs), freshwater reference (Lake Winnipeg), and marine reference (Bay of Fundy). All colonies were also pooled and then divided into high 2,3,7,8-tetrachlorodibenzo- $p$-dioxin toxicity equivalent (TCDD-TEQs > $500 \mathrm{pg} / \mathrm{g}$ ) or low TEQ (TCDDTEQs $<500 \mathrm{pg} / \mathrm{g}$ ), based on their TCDD-TEQ concentrations derived from congener-specific PCBs, polychlorinated dibenzop-dioxin (PCDD), and polychlorinated dibenzofuran (PCDF) concentrations in their livers using World Health Organization toxic equivalency factors (Van den Berg et al., 1998) for birds. Similarly, they were also grouped as high PCBs ( $\Sigma$ PCBs $>9500$ $\mathrm{ng} / \mathrm{g}$ ) or low PCBs ( $\mathrm{PPCBs}<9500 \mathrm{ng} / \mathrm{g}$ ) based on the sum of 42 congeners. These concentration groupings have no toxicological basis but were based on the natural separation of locations when ordered by concentration. See Fox et al. (2002) for details of the chemical analyses. The influence of the independent variables sex, body mass, bone length, and location on variation in the dependent variables body mass, bone length, and the various pQCT and biomechanical variables was assessed by analysis of covariance (ANCOVA). Thereafter, differences in continuous dependent variables between the locations or organohalogen groupings were analyzed using ANCOVA incorporating the appropriate independent variables of sex, body mass, and bone length, as necessary, to statistically control for their influence. Significance was assessed with the Bonferroni-Dunn test. Differences were considered significant at $p<.05$ (StatView, version 5.0; SAS Institute, Inc., Cary, NC).

\section{RESULTS}

\section{Sex, Body Mass, Femur Length, and Location as Sources of Variability}

The influence of the independent variables sex, body mass, bone length, and location on the variation in the dependent variables body mass, bone length, and the pQCT and biomechanical variables differed among the dependent variables (Table 2). Sex was a larger contributor to the variation in body

TABLE 2

Influence of the Independent Variables Sex, Body Mass, Bone Length and Location on Variation in the Different Dependent Variables Body Mass, Bone Length, and pQCT and Biomechanical Variables of Herring Gull Femurs, Based on ANCOVAs with Colonies Grouped as Great Lakes, Freshwater, and Marine

\begin{tabular}{|c|c|c|c|c|}
\hline \multirow[b]{2}{*}{ Dependent variables } & \multicolumn{4}{|c|}{ Independent variables } \\
\hline & Sex & Body mass & Bone length & Location \\
\hline Body mass & 405.2 & - & - & 6.4 \\
\hline Bone length & 33.0 & 2.9 & - & 6.0 \\
\hline Periosteal circumference & 0.7 & 8.2 & 9.0 & 3.3 \\
\hline Endosteal circumference & 0.0 & 2.1 & 3.6 & 1.4 \\
\hline Total cross-sectional area & 0.7 & 8.4 & 8.4 & 3.2 \\
\hline Cortical area & 4.3 & 16.0 & 6.9 & 2.9 \\
\hline Cortical thickness & 2.2 & 4.2 & 0.7 & 0.3 \\
\hline Cortical bone mineral content & 4.4 & 12.9 & 8.8 & 5.2 \\
\hline Cortical bone mineral density & 0.2 & 0.1 & 4.5 & 11.5 \\
\hline Displacement at failure & 0.4 & 1.2 & 0.3 & 5.2 \\
\hline Load at failure & 1.2 & 1.9 & 1.6 & 1.9 \\
\hline Energy required for failure & 0.0 & 2.3 & 0.1 & 4.2 \\
\hline Stiffness to failure & 1.9 & 0.1 & 2.9 & 2.3 \\
\hline
\end{tabular}

Note. ANCOVA provides a numerical value for the shared variance. Values shown are $F$ values $(F>3, p<.05)$. This $F$ value together with the degrees of freedom is used to calculate the $p$ value. 
mass and bone length than was location. Sex also contributed significantly to cortical bone mineral content and cortical area. Bone length was the largest contributor to variance in total area and both periosteal and endosteal femoral circumference. Bone length also contributed significantly to the variance in cortical bone mineral content, cortical bone mineral density, total cross-sectional area, and cortical area. Body mass was the largest contributor to variance in cortical bone mineral content, cortical area, and cortical thickness and contributed equally with bone length to the variance in total cross-sectional area. Body mass also contributed significantly to the variance in periosteal circumference. Location was the largest contributor to the variance in cortical bone mineral density, displacement at failure, and energy required for failure, and also contributed significantly to body mass, bone length, total cross-sectional area, cortical bone mineral content, and periosteal circumference.

\section{Body Mass and Bone Length}

After controlling for sex, body mass of individuals from Great Lakes colonies was $4.4 \%$ lower than that of individuals from the freshwater reference colony (Table 3). Body mass was also lower $(2.5 \%)$ in gulls from the high-TEQ colonies than in gulls from the low-TEQ colonies (Table 3).
When controlled for sex and body mass, femurs were shorter in individuals from Great Lakes colonies than those of individuals from the freshwater $(2.9 \%)$ and marine $(2 \%)$ reference colonies. Femur length did not differ between individuals from the freshwater and marine reference colonies, between the high- and low-TEQ colonies or between individuals of the high- and low-PCB colonies (Table 3 ).

\section{pQCT Measurements}

All pQCT variables were controlled for sex, body mass, and bone length. Cortical bone mineral density was significantly higher in gulls from the marine colony than in gulls from Great Lakes (2\%) and the freshwater colony $(2.6 \%)$ and was the only pQCT measure that differed between the two reference colonies (Table 3). The periosteal circumference (girth) of the femurs of Great Lakes gulls was smaller than those of gulls from the freshwater group $(2.4 \%)$ and the marine reference colony $(3 \%)$. The femurs of the Great Lakes gulls had smaller total cross-sectional areas than those of gulls from the freshwater group $(5.4 \%)$ and marine $(6.6 \%)$ reference colony. The femurs of the Great Lakes gulls had a markedly lower cortical bone mineral content $(8.1 \%)$ than femurs of gulls from the marine reference colony. Cortical area, cortical thickness, and

\section{TABLE 3}

Body Mass, Bone Length and Measurements Obtained from Quantitative Computed Tomography (pQCT-Analysis) of Femurs of Adult Herring Gulls Collected in 1991and 1993 From Great Lakes and Marine (Bay of Fundy) and Freshwater

(Lake Winnipeg) reference colonies

\begin{tabular}{|c|c|c|c|c|c|c|c|}
\hline Variable & $\begin{array}{l}\text { Marine } \\
\text { reference }\end{array}$ & $\begin{array}{l}\text { Freshwater } \\
\text { reference }\end{array}$ & $\begin{array}{l}\text { Great Lakes } 10 \\
\text { colonies }\end{array}$ & $\begin{array}{l}\text { Low TEQ } \\
<500 \mathrm{pg} / \mathrm{g}\end{array}$ & $\begin{array}{l}\text { High TEQ } \\
>500 \mathrm{pg} / \mathrm{g}\end{array}$ & $\begin{array}{l}\text { Low PCB } \\
<9500 \mathrm{ng} / \mathrm{g}\end{array}$ & $\begin{array}{l}\text { High PCB } \\
>9500 \mathrm{ng} / \mathrm{g}\end{array}$ \\
\hline ample size & 19 & 19 & 1( & 85 & 55 & 80 & 60 \\
\hline ody mass (g) & $1070 \pm 125$ & $1079 \pm 121$ & $1034 \pm 129^{\mathrm{aa}}$ & $1055 \pm 128$ & $1030 \pm 128^{\mathrm{ccc}}$ & $1047 \pm 132$ & $1043 \pm 123$ \\
\hline 3one length (mm) & $59.9 \pm 2.4$ & $60.4 \pm 2$ & $58.7 \pm 3.1^{\text {aaab }}$ & $59.1 \pm 3.0$ & $59.1 \pm 2.9$ & $59.0 \pm .0$ & $59.2 \pm 3.0$ \\
\hline $\begin{array}{l}\text { Periosteal } \\
\quad \text { circumference }(\mathrm{mm})\end{array}$ & $17.2 \pm 0.8$ & $17.1 \pm 0.9$ & $16.7 \pm 0.8^{\text {aabbb }}$ & $16.9 \pm 0.9$ & $16.7 \pm 0.8$ & $16.8 \pm 0.9$ & $16.8 \pm 0.8$ \\
\hline $\begin{array}{l}\text { Endosteal } \\
\quad \text { circumference }(\mathrm{mm})\end{array}$ & $13.7 \pm 0.8$ & $13.7 \pm 0.9$ & $13.3 \pm 0.9$ & $13.4 \pm 0.9$ & $13.3 \pm 0.9$ & $13.4 \pm 0.9$ & $13.4 \pm 0.9$ \\
\hline $\begin{array}{l}\text { Total cross-sectional } \\
\text { area }\left(\mathrm{mm}^{2}\right)\end{array}$ & $23.7 \pm 2.2$ & $23.4 \pm 2.4$ & $22.2 \pm 2.3^{\mathrm{aabbb}}$ & $22.7 \pm 2.5$ & $22.4 \pm 2.1$ & $22.6 \pm 2.5$ & $22.6 \pm 2.2$ \\
\hline Cortical area $\left(\mathrm{mm}^{2}\right)$ & $8.7 \pm$ & $8.4 \pm 1.1$ & \pm & $3 \pm 1.0$ & $8.2 \pm 0.9$ & 8.3 & $8.2 \pm 0.9$ \\
\hline Cortical thickness (mm) & $0.5 \pm 0$ & $0.6 \pm$ & $0.5 \pm$ & $0.6 \pm 0.1$ & $0.6 \pm 0.1$ & $0.6 \pm$ & $0.5 \pm 0.1$ \\
\hline $\begin{array}{l}\text { Cortical bone mineral } \\
\text { content }(\mathrm{mg} / \mathrm{mm})\end{array}$ & $12.0 \pm 1.2$ & $11.4 \pm 1.6$ & $11.1 \pm 1.3^{\mathrm{bbb}}$ & $11.3 \pm 1.4$ & $11.2 \pm 1.3$ & $11.3 \pm 1.5$ & $11.1 \pm 1.3$ \\
\hline $\begin{array}{l}\text { Cortical bone mineral } \\
\text { density }\left(\mathrm{mg} / \mathrm{cm}^{3}\right)\end{array}$ & $1388 \pm 26$ & $1353 \pm 27^{\mathrm{bbb}}$ & $1361 \pm 25^{\mathrm{bbb}}$ & $1364 \pm 27$ & $1363 \pm 27$ & $1366 \pm 27$ & $1360 \pm 27$ \\
\hline
\end{tabular}

Note. Colonies were also grouped by TCDD-TEQ and $\Sigma$ PCB concentrations in liver. Differences between groups were evaluated by ANCOVA and controlled for sex, body mass, and bone length (except the variable body mass, which was only adjusted for sex). Values are mean $\pm \mathrm{SD}$, measured at the diaphyseal measure point located at a distance of $40 \%$ of the total bone length measured from the distal tip.

${ }^{a}$ Significantly lower than the freshwater reference (a, $p<.05$, aa, $p<.01$, aaa, $\left.p<.001\right)$.

${ }^{b}$ Significantly lower than the marine reference $(\mathrm{b}, p<.05$, bb, $p<.01$, bbb, $p<.001)$.

${ }^{c}$ Significantly lower than the high-TEQ group (ccc, $\left.p<.001\right)$. 
endosteal circumference did not differ significantly between Great Lakes colonies and either the freshwater or marine reference colony (Table 3).

Although the body weight of the individuals of the highTEQ colonies was significantly lower than that of the low-TEQ colonies, there were no significant differences detected in bone composition between individuals of the two TEQ groups or between the low- and high-PCB colonies (Table 3).

\section{Biomechanical Variables}

All biomechanical variables were controlled for sex, body mass, and bone length. There were no significant differences in biomechanical variables between the freshwater and marine reference colonies (Table 4). Femurs of gulls from the Great Lakes had significantly greater displacement at failure (34\%) and energy required for failure (44\%) than gulls from the freshwater reference (Table 4). Femurs of Great Lakes gulls had significantly lower (16\%) stiffness to failure than those from the freshwater reference (Table 4). There were no significant differences in biomechanical properties between individuals of the high- and low-PCB colonies. However, gulls in the highTEQ group had significantly increased displacement at failure (11.3\%), load at failure (10.5\%), and energy required for failure (18\%) compared to gulls in the low-TEQ colonies (Tables 4).

\section{DISCUSSION}

Significant differences occurred in 9 of 13 variables between gulls from Great Lakes colonies and the freshwater and/or marine reference colony (Tables 3 and 4). In contrast, only cortical bone mineral density differed significantly between gulls from freshwater and marine reference colonies. Femurs of gulls from Great Lakes colonies were smaller (in length, girth, and cross section), and had lower bone mineral density, bone mineral content, and stiffness to failure than femurs from gulls from the freshwater and/or marine reference colony (Tables 3 and 4). In contrast, the femurs of Great Lakes gulls had a greater displacement at failure and required more energy for failure than did the femurs of gulls from the freshwater reference colony. The gulls from Great Lakes colonies and Lake Winnipeg can freely mix, but are genetically isolated from gulls from the Bay of Fundy (Weseloh, 1984; Yauk \& Quinn 1999). This would suggest that these differences in bone size, composition and strength are unlikely to be due to differences between the freshwater and marine environments or genotype, and more likely associated with sex, body size, or one or more localized factors such as diet and nutrition, and pollutant exposure.

\section{Sex}

Sex was greater contributor to variation in body mass and femur length than was location (Table 2), consistent with the genetic determination of body size in this sexually size dimorphic species. Sex was also a significant contributor to the variation in periosteal circumference (bone girth) and cortical area and mineral content, consistent with genetic and hormonal influences on phenotype and differences in the dynamics of bone in male and female birds.

\section{Bone Length and Body Mass}

Femur length is a reflection of body size, whereas body mass reflects both body size and tissue mass and is therefore an integrated measure of body condition and sensitive to localized

TABLE 4

Biomechanical Properties of Femurs of Adult Herring Gulls Collected in 1991 and 1993 from Great Lakes and Marine (Bay of Fundy) and Freshwater (Lake Winnipeg) Reference Colonies and when Grouped By TCDD-TEQ and PCB Concentrations in Liver

\begin{tabular}{|c|c|c|c|c|c|c|c|}
\hline Variable & $\begin{array}{l}\text { Marine } \\
\text { reference }\end{array}$ & $\begin{array}{l}\text { Freshwater } \\
\text { reference }\end{array}$ & $\begin{array}{l}\text { Great Lakes } \\
\text { (10 colonies })\end{array}$ & $\begin{array}{l}\text { Low TEQ } \\
<500 \mathrm{pg} / \mathrm{g}\end{array}$ & $\begin{array}{l}\text { High TEQ } \\
>500 \mathrm{pg} / \mathrm{g}\end{array}$ & $\begin{array}{l}\text { Low PCB } \\
<9500 \mathrm{ng} / \mathrm{g}\end{array}$ & $\begin{array}{l}\text { High PCB } \\
>9500 \mathrm{ng} / \mathrm{g}\end{array}$ \\
\hline Sampl & 19 & 1 & 1 & 8 & 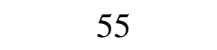 & 80 & 60 \\
\hline $\begin{array}{l}\text { Displacement at } \\
\text { failure }(\mathrm{mm})\end{array}$ & $12 \pm$ & $4 \pm$ & $26=$ & 9 & $1.28 \pm$ & $1.15 \pm 0.36$ & $1.26 \pm 0.45$ \\
\hline Load at failure $(\mathrm{N})$ & $143.1 \pm$ & 0.5 & -4.7 & $136.9 \pm$ & $151.3 \pm$ & 139.6 & 146.6 \\
\hline $\begin{array}{l}\text { Energy required for } \\
\text { failure }(\mathbf{J})\end{array}$ & $127.1 \pm 47.7$ & $100.8 \pm 67.8$ & $145.6 \pm 68.1^{\text {aa }}$ & $128.0 \pm 65.6$ & $151.1 \pm 67.7^{\mathrm{c}}$ & $148.3 \pm 44.5$ & $147.4 \pm 46.8$ \\
\hline $\begin{array}{l}\text { Stiffness to } \\
\text { failure }(\mathrm{N} / \mathrm{mm})\end{array}$ & $152.7 \pm 35.0$ & $170.5 \pm 51.1$ & $142.8 \pm 44.9^{\text {aa }}$ & $148.0 \pm 45.0$ & $147.8 \pm 46.1$ & $128.5 \pm 63.1$ & $148.3 \pm 71.1$ \\
\hline
\end{tabular}

Note. Values are mean $\pm \mathrm{SD}$, measured at the diaphyseal measure point located at a distance of $40 \%$ of the total bone length measured from the distal tip. Differences between groups were evaluated by ANCOVA and controlled for sex, body mass, and bone length. Values in bold are significantly different from the freshwater reference (a) or contrasting concentration grouping (c). 
environmental factors. Variations in cross-sectional and cortical area, periosteal and endosteal circumference, and cortical bone mineral content and density were significantly influenced by bone length (Table 2). Body mass significantly influenced variability in cross-sectional and cortical area, periosteal circumference, cortical thickness, and cortical bone mineral concentration (Table 2). These findings reflect the influence of body mass and length on the physical stresses on bones and their influence on the remodeling process. Bone adapts to mechanical stresses largely by changing its size and shape (Turner 2006).

\section{Location}

Location was a significant contributor to variability in body mass, bone length, cross-sectional and cortical area, and cortical bone mineral content and density, and in the strength properties displacement and energy at failure (Table 2).

Small increases in bone mineral density can markedly improve bone strength (Turner, 2006). Cortical bone mineral density was the only variable that differed significantly between the freshwater and marine reference sites (Table 3). The reasons for this observation remain to be clarified. Altered bone mineral density was reported in studies of additional species of free-ranging wildlife, including the skulls and bacula of East Greenland polar bears (Ursus maritimus) (Sonne et al., 2004, 2006), the jaws and radius of Baltic gray seals (Halichoerus grypus) (Lind et al., 2003), and the tibias and femurs of American alligators (Alligator mississippiensis) (Lind et al., 2004). Cortical bone mineral content of femurs of gulls from Great Lakes colonies was significantly lower than that of gulls from the marine reference colony. Total cross-sectional area and cortical area of femurs of gulls from the Great Lakes were significantly smaller than those of gulls from both the freshwater and marine reference colonies.

Location was the only measured variable that contributed significantly to the variance in biomechanical properties (Table 2). While there were no significant differences in these properties between the freshwater and marine reference sites, the displacement at failure and the energy required for failure were significantly greater for the femurs of gulls from the Great Lakes relative to the freshwater reference colony (Table 4). Displacement at failure and energy required for failure were 34 and $31 \%$ greater, respectively, overall, while stiffness at failure was $16 \%$ less. Therefore, gulls from the Great Lakes colonies had softer and more plastic bones than those of gulls from the freshwater reference colony. While there were no significant decreases in length and girth, crosssectional area, and mineral concentration or density between high-PCB and low-PCB colonies or high-TEQ and low-TEQ colonies, the femurs of the high-TEQ colonies had significantly higher displacement at failure, energy required for failure, and load at failure than those from gulls from the lowTEQ colonies.
Effects of PCB (Andrews, 1989; Hoffman et al., 1996; Lind et al., 1999, 2000; Lundberg et al., 2006) and PCDD (Jämsä et al., 2001; Miettinen et al., 2005) on bone tissue include decreased length and cross-sectional area, alterations in mineral density, and decreased strength following controlled exposure. The mineral density of skull bones of East Greenland polar bears was negatively related to PCBs, polybrominated diphenyl ethers (PBDEs), and other organohalogen pollutants (Sonne et al., 2004). The length and mineral density of the penis bone (baculum) of these polar bears decreased significantly with increasing levels of several organohalogen pollutants in their adipose tissue (Sonne et al., 2006). In a similar manner, organohalogen pollutants may have impaired bone growth and mineralization in Great Lakes gulls, producing altered bone growth and mineralization. Bone consists of a collagenous organic matrix with embedded hydroxyapatite crystals $\left[\mathrm{Ca}_{5}\left(\mathrm{PO}_{4}\right)_{3}(\mathrm{OH})\right]$. Without sufficient mineralization, bones will plastically deform under load (Turner, 2006). The measured plasma concentrations of $\mathrm{Ca}$ and $\mathrm{P}$ in the gulls show that individuals from the Great Lakes area had significantly lower concentrations compared to gulls from the freshwater reference (Fox et al., 2007b). Plasma calcium concentrations were significantly lower in the gulls from Great Lakes relative to the gulls from the freshwater reference, and were lower in gulls from the high-PCB colonies than in those from the lowPCB colonies (Fox et al., 2007b). In addition, plasma inorganic phosphorus concentrations were significantly lower in the gulls from the Great Lakes relative to the gulls from the freshwater reference (Fox et al., 2007b). Effects on plasma $\mathrm{P}$ has also been reported in other species. Smits et al. (2007) reported decreased plasma inorganic phosphate concentrations in breeding colonies of white stork (Ciconia ciconia) in southwestern Spain accidentally exposed to large amounts of acidic and metal-rich water. Serum phosphorus concentrations were significantly reduced at low doses and significantly increased in the highest dose of a complex mixture of organohalogen pollutants and lead and cadmium in orally exposed male rats (Wade et al., 2002). Magnesium is another important constituent of bone mineral; a deficiency in $\mathrm{Mg}$ inhibits the osteoblastic activity (Palacios, 2006). Plasma magnesium concentrations were significantly lower in Great Lakes gulls than in the freshwater reference and were significantly lower in the high-PCB colonies than the low-PCB colonies (Fox et al., 2007a). Plasma magnesium concentrations were inversely associated with nonortho-PCB and TCDD-TEQ concentrations in individual livers (Fox et al., 2007a). Plasma magnesium concentrations in loggerhead sea turtles (Caretta caretta) from North Carolina were inversely associated with $\Sigma$ PCBs and TCDD-like PCB concentrations in blood (Keller et al., 2004).

Since steroid hormones are needed to maintain the equilibrium between the formation and destruction of bone, the interference of a pollutant displaying anti-estrogenic/antiandrogenic or estrogenic/androgenic properties might alter bone size and composition. The mechanisms underlying altered 
bone composition might involve interference with the androgen/estrogen receptor (AR/ER) signaling pathway, the aryl hydrocarbon receptor (AhR) pathway, or cross-talk between these pathways. Published studies suggest some environmental pollutants do disrupt estrogen homeostasis (Lind et al., 2000; Lundberg et al., 2006). Moreover, these effects may be developmental and/or induced later in life, since the gulls are exposed in ovo through adulthood. Median EROD activities (in the AhR pathway) in the livers of the gulls from the various Great Lakes colonies were approximately 3- to 10 -fold greater than gulls from the freshwater reference (Fox et al., 2007b). EROD activity was significantly greater in the high-PCB colonies than in the low-PCB colonies. EROD activity was significantly associated with $\Sigma$ PCDDs in pooled livers and lead in pooled kidneys (Fox et al., 2007b).

The hormone thyroxine also plays an important role in the regulation of bone growth and chondrocyte differentiation (Ren et al., 2007). Although plasma thyroxine concentrations were not significantly lower in the iodine-deficient freshwater reference colony and the iodine-sufficient marine colony, concentrations in gulls from lakes Erie, Ontario, and Huron and the Detroit River were markedly lower than those from both the reference colonies (Fox et al., 2007b). Median plasma thyroxine concentrations of gulls in the high-PCB colonies were significantly lower than those of the low-PCB colonies and were inversely associated with $\triangle \mathrm{PCB}$ concentrations in liver (Fox et al., 2007b). PCBs, PCDD, and PBDE are persistent bioaccumulative organohalogen pollutants that are known to affect thyroid function and to which herring gulls are heavily exposed (Hebert et al., 1999a; Norstrom et al., 2002).

Vitamin $\mathrm{D}_{3}$ is a major hormone involved in the regulation of calcium metabolism and skeletal remodeling. Osteomalacia, a condition characterized by soft and demineralized bones (Shoback 2007), can result from vitamin D deficiency. The most consistent abnormality observed in vitamin $\mathrm{D}_{3}$ deficiencyinduced osteomalacia in humans is hypophosphatemia, which is not always accompanied by hypocalcemia (Catto, 1985). Long-Evans rat dams and their offspring showed reduced serum levels of 1,25-dihydroxyvitamin $\mathrm{D}_{3}$ following exposure to a mixture of PCBs (Lilienthal et al., 2000). Unfortunately, the vitamin $\mathrm{D}$ or $\mathrm{D}_{3}$ concentrations were not measured in these gulls.

In conclusion, the effects on bone size, mineral content, and strength observed in Great Lakes herring gulls may be less likely attributed to genetic than local environmental factors. The relative influence of nutrition and toxic pollutants is unclear, although several pollutants to which birds are chronically exposed have been implicated as bone toxins. Many potential mechanisms for adverse effects exist. However, since the gulls were exposed to different compounds/concentrations at different life stages and over time, it is difficult to draw any certain conclusions as to which specific toxicant(s) induced the observed alterations in bone tissue and whether the effects are primary or secondary. Our findings further enlarge the suite of environmental diseases observed in this collection of gulls and add to the growing body of evidence that place of residence, in this case the Great Lakes, affects the well-being of individuals.

\section{REFERENCES}

Andrews, J. E. 1989. Polychlorinated biphenyl (Aroclor 1254) induced changes in femur morphology calcium metabolism and nephrotoxicity. Toxicology 57:83-96.

Andrews, J. E., Courtney, K. D., and Donaldson, W. E. 1988. Impairment of calcium homeostasis by hexachlorobenzene (HCB) exposure in Fischer 344 rats. J. Toxicol. Environ. Health 23:311-320.

Beckett, K. J., Millsap, S. D., Blankenship, A. L., Zwiernik, M. J., Giesy, J. P., and Bursian, S. J. 2005. Squamous epithelial lesion of the mandibles and maxillae of wild mink (Mustela vison) naturally exposed to polychlorinated biphenyls. Environ. Toxicol. Chem. 24: 674-677.

Bhattacharyya, M. H., Whelton, B. D., Peterson, D. P., Carnes, B. A., Moretti, E. S., Toomey, J. M., and Williams, L. L. 1998. Skeletal changes in multiparous rats fed a nutrient-sufficient diet containing cadmium. Toxicology 50:193-2004.

Catto, M. E. 1985. Locomotor System. In Muir's Textbook of Pathology, 12th ed., ed. J. R. Anderson, pp. 23.1-23.72. London: Edward Arnold Ltd.

Ewins, P. J., Weseloh, D. V., Groom, J. H., Dobos, R. Z., and Mineau, P. 1994. The diet of herring gulls (Larus argentatus) during winter and early spring in the Lower Great Lakes. Hydrobiologica 279/280:39-55.

Firling, C. E., Hill, T. A., and Severson, A. R. 1999. Aluminum toxicity perturbs long bone calcification in the embryonic chick. Arch. Toxicol. 73:359-366.

Fox, G. A., Allan, L. J., Weseloh, D. V., and Mineau, P. 1990. The diet of herring gulls during the nesting period in Canadian waters of the Great Lakes. Can. J. Zool. 68:1075-1085.

Fox, G. A., Grasman, K. A., Hobson, K. A., Williams, K., Jeffrey, D., and Hanbidge, B. 2002. Contaminant residues in tissues of adult and prefledged herring gulls from the Great Lakes in relation to diet in the early 1990s. $J$. Great Lakes Res. 28:643-663.

Fox, G. A., White, P. A., Trudeau, S., Theodorakis, C., Shutt, L. J., Kennedy, S. W., and Fernie, K. J. 2005. DNA strand length and EROD activity in relation to two screening measures of genotoxic exposure in Great Lakes herring gulls. Ecotoxicology 14:527-544.

Fox, G. A., Grasman, K. A., and Campbell, G. D. 2007a. Health of herring gulls (Larus argentatus) in relation to breeding location in the early 1990s. II. Cellular and histopathological measures. J. Toxicol. Environ. Health A 17:1471-1491.

Fox, G. A., Jeffrey, D. A., Williams, K. S., Kennedy, S. W., and Grasman, K. A. 2007b. Health of herring gulls (Larus argentatus) in relation to breeding location in the early 1990s. I. Biochemical measures. J. Toxicol. Environ. Health A 70:1443-1470.

Gilman, A. P., Fox, G. A., Peakall, D. B., Teeple, S. M., Carroll, T. R., and Haymes, G. T. 1977. Reproductive parameters and egg contaminant levels of Great Lakes herring gulls. J. Wildl. Manage. 41:458-468.

Grasman, K. A., Scanlon, P. F., and Fox, G. A. 2000. Geographic variation in haematological variables in adult and prefledgling herring gulls (Larus argentatus) and possible associations with organochlorine exposure. Arch. Environ. Contam. Toxicol. 38:244-253.

Hahn, T. J. 1989. Aluminum-related disorders of bone and mineral metabolism. Bone Miner. Res. 6:219-265.

Hart, L. E., Cheng, K. M., Whitehead, P. E., Shah, R. M., Lewis, R. J., Ruschkowski S. R., Blair, R. W., Bennett, D. C., Bandiera, S. M., Norstrom, R. J., and Bellward, G. D. 1991. Dioxin contamination and growth and development in great blue heron embryos. J. Toxicol. Environ. Health 32:331-344.

Hebert, C. E. 1998. Winter severity affects migration and contaminant accumulation in northern Great Lakes herring gulls. Ecol. Appl. 8:669-679.

Hebert, C. E., Norstrom, R. J. and Weseloh, D. V. 1999a. A quarter century of environmental surveillance: The Canadian Wildlife Service's Great Lakes Herring Gull Monitoring Program. Environ. Rev. 7:147-166. 
Hebert, C. E., Shutt, J. L., and Ball, R. O. 2002. Plasma amino acid concentrations as an indicator of protein availability to breeding herring gulls (Larus argentatus). Auk 119:185-200.

Hebert, C. E., Shutt, J. L., Hobson, K.A., and Weseloh, D. V. 1999b. Spatial and temporal differences in the diet of Great Lakes herring gulls (Larus argentatus): Evidence from stable isotope analysis. Can. J.Fish. Aquat. Sci. $56: 323-338$

Hoffman, D. J., Melancon, M. J., Klein, P. N., Rice, C. R., Eisemann, J. D., Hines, R. K., Spann, J. W., and Pendleton, G. W. 1996. Developmental toxicity of PCB 126 (3,3',4,4',5-pentachlorobiphenyl) in nestling American kestrels (Falco spaverius). Fundam. Appl. Toxicol. 34:188-200.

Jämsä, T., Viluksela, M., Tuomisto, J. T., Tuomisto, J., and Tuukkanen, J. 2001. Effects of 2,3,7,8-tetrachlorodibenzo- $p$-dioxin on bone in two rats strains with different aryl hydrocarbon receptor structures. J. Bone Miner. Res. 16:1812-1820.

Keller, J. M., Kucklick, J. R., Stamper, M. A., Harms, C. A., and McClellanGreen, P. D. 2004. Relationship between organochlorine contaminant concentrations and clinical health parameters in loggerhead sea turtles from North Carolina, U.S.A. Environ. Health. Perspect. 112:1074-1079.

Lanham-New, S. A., and Bonjour, J.-P., eds. 2003. Nutritional aspects of bone health. London: Royal Society of Chemistry.

Lilienthal, H., Fastabend, A., Hany, J., Kaya, H., Roth-Harer, A., Dunemann, L., and Winneke, G. 2000. Reduced levels of 1,25-dihydroxyvitamin D(3) in rat dams and offspring after exposure to a reconstituted PCB mixture. Toxicol. Sci. 57:292-301.

Lind, P. M., Bergman, A., Olsson, M., and Örberg, J. 2003. Bone mineral density in male Baltic grey seal (Halichoerus grypus). Ambio 32:385-388.

Lind, P. M., Eriksen, E. F., Sahlin, L., Edlund, M., and Orberg, J. 1999. Effects of the antiestrogenic environmental pollutant 3,3',4,4',5-pentachlorobiphenyl (PCB \#126) in rat bone and uterus: Diverging effects in ovariectomized and intact animals. Toxicol. Appl. Pharmacol. 154:236-244.

Lind, P. M., Larson, S., Oxlund, H., Håkansson, H., Nyberg, K., Eklund, T., and Örberg, J. 2000. Change in bone tissue composition and impaired bone strength in rats exposed to $3,3^{\prime}, 4,4^{\prime}, 5$-penachlorobiphenyl (PCB 126). Toxicology 150:41-51.

Lind, P. M., Milnes, M. R., Lundberg, R., Bermudez, D., Orberg, J. A., and Guillette, L. J., Jr. 2004. Abnormal bone composition in female juvenile American alligators from a pesticide-polluted lake (Lake Apopka, Florida). Environ. Health Perspect. 112:359-362.

Lundberg, R., Jenssen, B. M., Leiva-Presa, A., Ronn, M., Hernhag, C., Wejheden, C., Larsson, S., Orberg, J., and Lind, P. M. 2007. Effects of short-term exposure to the DDT metabolite $p, p^{\prime}$-DDE on bone tissue in male common frog (Rana temporaria). J. Toxicol. Environ. Health A 70:614-619.

Lundberg, R., Lyche, J. L, Ropstad, E., Aleksandersen, M., Ronn, M., Skaare, J. U., Larsson, S., Orberg, J., and Lind, P. M. 2006. Perinatal exposure to PCB 153, but not PCB 126, alters bone tissue composition in female goat offspring. Toxicology 228:33-40.

Miettinen, H. M., Pulkkinen, P., Jämsä, T., Koistinen, J., Simanainen, U., Tuomisto, J., Tuukkanen, J., and Viluksela, M. 2005. Effects of in utero and lactational TCDD exposure on bone development in differentially sensitive rat lines. Toxicol. Sci. 85:1003-1012.

Norstrom, R. J., Simon, M., Moisy, J., Wakeford, B., and Weseloh, D. V. C. 2002. Georaphical distribution (2000) and temporal trends (1981-2000) of brominated diphenyl ethers in Great Lakes herring gull eggs. Environ. Sci. Technol. 36:4783-4789.

Palacios, C. 2006. The role of nutrients in bone health, from A to Z. Crit. Rev. Food Sci. Nutr. 46:621-628.

Potula, V., Kleinbaum, D., and Kaye, W. 2006. Lead exposure and spine bone mineral density. J. Occup. Environ. Med. 48:556-564.

Ren, F. L., Guo, X., Zhang, R. J., Wang, S. J., Zuo, H., Zhang, Z. T., Geng, D.,Yu, Y., and Su, M. 2007. Effects of selenium and iodine deficiency on bone, cartilage growth plate and chondrocyte differentiation in two generations of rats. Osteoarthritis Cartil. 15:1171-1177.

Rodriguez-Navarro, A. B., Romanek, C. S., Alvarez-Lloret, P., and Gaines, K. F. 2006. Effect of in ovo exposure to $\mathrm{PCBs}$ and $\mathrm{Hg}$ on clapper rail bone mineral chemistry from a contaminated salt marsh in coastal Georgia. Environ. Sci. Technol. 40:4936-4942.

Seibel, M. J., Robins, S. P., and Bilezikian, J. P. 1999. Dynamics of bone and cartilage metabolism. New York: Academic Press.

Shoback, D. 2007. Update in osteoporosis and metabolic bone disorders. $J$. Clin. Endocrinol. Metab. 92:747-753.

Smits, J. E., Bortolotti, G. R., Baos, R., Jovani, R., Tella, J. L., and Hoffmann, W. E. 2007. Disrupted bone metabolism in contaminant-exposed white storks (Ciconia ciconia) in southwestern Spain. Environ. Pollut. 145:538-544.

Sonne, C., Dietz, R., Born, E. W., Riget, F. F., Kirkegaard, M., Hyldstrup, L., Letcher, R. J., and Muir, D. J. 2004. Is bone mineral composition disrupted by organochlorines in East Greenland polar bears (Ursus maritimus)? Environ. Health Perspect. 112:1711-1716.

Sonne, C., Leifsson, P. S., Dietz, R., Born, F. W., Letcher, R. J., Hyldstrup, L., Riget, F. F., Kirkegaard, M., and Muir, D. C. G. 2006. Xenoendocrine pollutants may reduce size of sexual organs in East Greenland polar bears (Ursus maritimus). Environ. Sci. Technol. 40:5668-5674.

Thompson, H. M., Fernandes, A., Rose, M., White, S., and Blackburn, A. 2006. Possible chemical causes of skeletal deformities in grey heron nestlings (Ardea cinerea) in North Nottinghamshire, UK. Chemosphere 65:400-409.

Turner, C. H. 2002. Biomechanics of bone: determinants of skeletal frigility and bone quality. Osteoporos Int. 13:97-104.

Turner, C. H. 2006. Bone strength: current concepts. Ann. NY Acad. Sci. 1068:429-446.

Van den Berg, M., Birnbaum, L., Bosveld, A. T. C., Brunstrom, B., Cook, P., Feely, M., Giesy, J. P., Hanberg, A., Hasegawa, R., Kennedy, S. W., Kubiak, T., Larsen, J. C., van Leeuwen, F. X. R., Leim, A. K. D., Nolt, C., Peterson, R. F., Poellinger, L., Safe, S., Schrenk, D., Tillitt, D., Tysklind, M., Younes, M., Waern, F., and Zacharewski, T. 1998. Toxic equivalency factors (TEFs) for PCBs, PCDDs, PCDFs for humans and wildlife. Environ. Health Perspect. 106:775-792.

Wade, M. G., Foster, W. G., Younglai, E. V., McMahon, A., Leingartner, K., Yagminas, A., Blakey, D., Fournier, M., Desaulniers, D., and Hughes, C. L. 2002. Effects of subchronic exposure to a complex mixture of persistent contaminants in male rats: Systemic, immune, and reproductive effects. Toxicol. Sci. 67:131-143.

Weseloh, D. V. 1984. The origins of banded herring gulls recovered in the Great Lakes. J. Field Ornithol. 55:190-195.

Yauk, C. L., and Quinn, J. S. 1999. Genetic structure among breeding herring gulls (Larus argentatus) from the Great Lakes and Eastern Canada. J. Great Lakes Res. 25:856-864. 